\title{
PENERAPAN MODEL AUDITORY INTELLECTUALLY REPETITION UNTUK MENINGKATKAN HASIL BELAJAR PPKn TEMA 5 PADA SISWA KELAS III SDN 5 PANJER TAHUN 2019/2020
}

\author{
Herlina $^{1}$, Muhamad Chamdani ${ }^{2}$, Tri Saptuti Susiani ${ }^{3}$ \\ 1,2,3 Universitas Sebelas Maret \\ herlina28@student.uns.sc.id
}

\section{Article History}

accepted 01/10/2020

\begin{abstract}
:
The study aimed: to improve Pancasila and Civic Education learning outcomes of theme 5 through the application of auditory intellectually repetition. It was collaborative classroom action research between researcher and teacher carried out in three cycles. The subjects were third grade students of SDN 5 Panjer. The data collection techniques used tests and non-tests. The data validity used triangulation of source and triangulation of method. The data analysis included data reduction, data presentation, and drawing conclusions. The results of the study indicated that the application of auditory intellectually repetition model improved Pancasila and Civic Education learning outcomes of theme 5. The increasing of students learning outcomes showed $52.08 \%$ in the first cycle, $85.42 \%$ in the second cycle, and $95.83 \%$ in the third cycle. It concludes that the application of auditory intellectually repetition improves Pancasila and Civic Education learning outcomes of theme 5 to third grade students of SDN 5 Panjer in academic year of 2019/2020.
\end{abstract}

Keywords: auditory intellectually repetition, learning outcomes, Pancasila and Civic Education

\begin{abstract}
Abstrak
Penelitian ini bertujuan untuk : meningkatkan hasil belajar PPKn tema 5 melalui penerapan model auditory intellectually repetition. Penelitian ini merupakan penelitian tindakan kelas kolaboratif antara peneliti dan guru yang dilaksanakan dalam tiga siklus. Subjek penelitian ini adalah siswa kelas III SDN 5 Panjer. Teknik dalam pengumpulan data terdiri dari tes dan nontes. Validitas data diuji menggunakan strategi triangulasi sumber dan metode. Analisis data terdiri dari reduksi data, penyajian data, dan kesimpulan. Hasil penelitian ini menunjukkan bahwa peningkatan hasil belajar siswa dengan penerapan model auditory intellectually repetition oleh guru pada siklus I-III, yaitu: $52.08 \%, 85.42 \%, 95.83 \%$. Kesimpulan dari hasil penelitian ini adalah penerapan model auditory intellectually repetition dapat meningkatkan Hasil Belajar PPKn Tema 5 Kelas III SDN 5 Panjer Tahun Ajaran 2019/2020.
\end{abstract}

Kata kunci: Auditory intellectually Repetition, hasil belajar, PPKn 


\section{PENDAHULUAN}

Pendidikan merupakan proses kemampuan individu yang akan terus berkembang seiring berjalanya waktu, melalui sebuah pembelajaran serta pengalaman. Sholichah (Agustina, Santoso, \& Jatisunda, 2019:635) menyatakan bahwa "Pendidikan merupakan sebagai usaha sadar dan terencana yang dilakukan oleh keluarga, sekolah, masyarakat dengan memberikan bimbingan, pengetahuan, keterampilan dan pembekalan budi pekerti".

Pendidikan menjadi salah satu tumpuan dan harapan suatu bangsa untuk membentuk masyarakat yang berkarakter maka dari itu masyarakat disarankan untuk mengeyam pendidikan di sekolah. Karena di sekolah terdapat mata pelajaran yang mampu membentuk karakter kenegaraan misalnya Pendidikan pancasila dan kewarganegaraan. Pendidikan pancasila dan kewarganegaraan atau yang disebut PPKn adalah mata pelajaran yang sangat berperan dalam pembentukan karakter kenegaraan pada siswa sekolah dasar. Hal ini dibuktikan dalam PP RI Nomor 32 Tahun 2013 tentang Perubahan atas Peraturan Pemerintah No 19 Tahun 2005 tentang Standar Nasional Pendidikan pasal 77 i ayat (1) yang menyebutkan bahwa suatu muatan mata pelajaran yang dimaksudkan untuk membentuk peserta didik menjadi manusia yang memiliki rasa kebangsaan dan cinta tanah air dalam konteks nilai dan moral pancasila kesadaran kontribusi Undang-Undang Dasar Negara Republik Indonesia Tahun 1945, nilai dan semangat Bhineka Tunggal Ika, serta komitmen Negara Kesatuan Republik Indonesia.

Berdasarkan kaitannya dengan pembelajaran PPKn, peneliti melakukan observasi pada saat magang kependidikan 3 yang dilaksanakan pada hari Rabu, 6 November 2019 di kelas III SD Negeri 5 Panjer, diperoleh data bahwa pembelajaran PPKn yang telah berjalan terdapat fakta bahwa: (1) beberapa siswa cepat merasa bosan, (2) beberapa siswa tidak tertarik mengikuti pelajaran, (3) beberapa siswa tidak memperhatikan penjelasan guru, dan (4) beberapa hasil belajar siswa belum maksimal. Untuk memperkuat hasil observasi maka peneliti melakukan wawancara kepada guru kelas III dengan hasil wawancara yang dilakukan pada tanggal 11 November 2019 didapatkan data bahwa dari 24 siswa di kelas III hanya 10 siswa yang memperoleh nilai diatas KKM, dan 14 siswa kurang dari KKM. Hal ini menunjukan bahwa $41 \%$ siswa mendapat nilai diatas KKM, dan 59\% siswa mendapat nilai dibawah KKM.

Pendidikan dapat dikatakan berhasil apabila hasil belajar peserta didik tinggi dan meningkat, dalam upaya untuk meningkatkan hasil belajar, maka seorang guru perlu melakukan inovasi pembelajaran misalnya, meningkatkan kualitas pembelajaran dengan menggunakan model pembelajaran yang baru dan menarik, dan memanajemen kelas dengan baik. Upaya guru untuk meningkatkan kualitas pembelajaran yaitu menggunakan model pembelajaran yang menarik dan efektif. Penggunaan model pembelajaran yang efektif merupakan solusi yang tepat untuk permasalahan tersebut, salah satu model pembelajaran yang efektif yaitu Auditory, Intellectually, Repetition (AIR). Shoimin (2014:226) mengemukakan bahwa "model AIR merupakan model pembelajaran yang berbasis berpikir dan berbasis masalah." Model ini menggunakan tiga tahapan yaitu mendengar, berpikir dan mengulangi, tiga tahap ini membuat pembelajaran lebih efektif. Hal ini diperkuat oleh pendapat Yennita (Linuwih\&Sukwati, 2014:159) model pembelajaran AIR menganggap bahwa "suatu proses pembelajaran akan lebih efektif jika memperhatikan tiga hal, yaitu Auditory (mendengar), Intellectually (berpikir) dan Repetition (pengulangan)".

Auditory atau pendengaran menurut Handayani, Suartana, \& Sentosa (2019:02) pada pembelajaran ini siswa belajar dari suara, dialog, menceritakan kepada orang lain sebuah pengalaman, belajar dan berbicara dengan diri sendiri, mengingat bunyi dan irama, mendengarkan kaset dan dari mengulang apa yang dibaca dalam hati. Menurut Handayani, Suartana, \&Sentosa (2019:02) Intellectually atau tahap proses berpikir, 
berarti menunjukkan apa yang dilakukan siswa dalam pikiran mereka secara internal ketika mereka menggunakan kecerdasan untuk merenungkan suatu pengalaman, menciptakan hubungan, makna, rencana, dan nilai dari pengalaman tersebut. Sedangkan Repetition atau tahap proses pengulangan, pada tahap pengulangan bertujuan untuk memahami materi secara mendalam dengan cara yang efektif serta menarik. Menurut Suherman (Shoimin,2014:226) Repetition merupakan pengulangan, dengan tujuan memperdalam dan memperluas pemahaman siswa yang perlu dilatih melalui pengerjaan soal, pemberian tugas dan kuis.

Langkah-langkah model pembelajaran AIR menurut Shoimin (2014: 30) yaitu: (1) Siswa dibagi menjadi beberapa kelompok, masing-masing kelompok beranggotakan 45 siswa; (2) Siswa mendengarkan dan memperhatikan penjelasan dari guru; (3) Setiap kelompok mendiskusikan materi yang mereka pelajari, dan menuliskan hasil diskusi tersebut kemudian dipresentasikan (Auditory); (4) Saat diskusi berlangsung, siswa mendapat soal atau permasalahan yang berkaitan dengan materi; (5) Masing-masing kelompok memikirkan cara menerapkan hasil diskusi serta dapat meningkatkan kemampuan mereka untuk menyelesaikan masalah (Intellectually); (6) Setelah selesai berdiskusi, siswa mendapatkan pengulangan materi dengan cara mendapatkan tugas atau kuis untuk tiap individu (Repetition). Langkah-langkah model pembelajaran $A I R$ (Auditory Intellectually Repetition) yang diterapkan dalam penelitian ini yaitu: (1) penyampian materi (auditory); (2) diskusi kelompok (intellectually); (3) presentasi hasil diskusi Kelompok (auditory); (4) pengulangan materi (repetition).

Berdasarkan latar belakang di atas maka peneliti tertarik untuk mengadakan penelitian tindakan kelas yang bertujuan untuk: (1) Mendeskripsikan langkah-langkah Penerapan Model Auditory Intellectually Repetition untuk Meningkatkan Hasil Belajar PPKn Tema 5 Kelas III SDN 5 Panjer Tahun Ajaran 2019/2020. (2) Meningkatkan Hasil Belajar PPKn Tema 5 melalui Model Auditory Intellectually Repetition Kelas III SDN 5 Panjer Tahun Ajaran 2019/2020. (3) Mendiskripsikan kendala dan solusi Penerapan Model Auditory Intellectually Repetition untuk Meningkatkan Hasil Belajar PPKn Tema 5 Kelas III SDN 5 Panjer Tahun Ajaran 2019/2020.

\section{METODE}

Penelitian ini merupakan penelitian tindakan kelas yang dilaksanakan secara kolaborasi antara peneliti dengan guru kelas. Subjek penelitian ini adalah seluruh siswa kelas III B SDN 5 Panjer Tahun Ajaran 2019/2020. Sumber data dalam penelitian ini adalah siswa, guru, observer, dan dokumen kelas III B SDN 5 Panjer yang terdiri dari 24 siswa. Teknik pengumpulan data menggunakan observasi, wawancara, dokumentasi dan tes. Uji validitas data menggunakan triangulasi teknik dan sumber. Analisis data terdiri dari reduksi data, penyajian data, dan kesimpulan (Sugiyono (2015: 336).

Aspek yang diukur dalam indikator kinerja penelitian ini adalah Pelaksanaan penerapan model AIR didalam pembelajaran PPKn Tema 5 dan ketuntasan hasil belajar setelah menerapkan model AIR dengan langkah (1) penyampian materi (auditory); (2) diskusi kelompok (intellectually); (3) presentasi hasil diskusi Kelompok (auditory); (4) pengulangan materi (repetition) dengan persentase yang ditargetkan sebesar $85 \%$. Penelitian ini menggunakan prosedur penelitian Kemmis dan Taggart (Arikunto,2013:137), yaitu terdiri dari tahap perencanaan, pelaksanaan, pengamatan, dan refleksi.

\section{HASIL DAN PEMBAHASAN}

Penerapan model Auditory Intellectually Repetition pada muatan pelajaran PPKn pada Tema 5 dilaksanakan dalam tiga siklus. Setiap siklus terdiri dari dua pertemuan, kecuali siklus terakhir hanya satu kali pertemuan. Pembelajaran yang dilaksanakan pada siklus I sampai siklus III terdiri dari empat langkah pembelajaran, yaitu: (1) 
penyapian materi (auditory); (2) diskusi kelompok (intellectually); (3) penyampaian hasil diskusi kelompok (auditory); (4) pengulangan materi (repetition). Penerapan pembelajaran dengan model Auditory Intellectually Repetition tersebut, sesuai dengan langkah-langkah model Auditory Intellectually Repetition yang dikemukakan oleh Manurung (2016); Shoimin (2014: 30); Huda (2014:290); Linuwih\&Sukwati (2014)

Penerapan model Auditory Intellectually Repetition mengalami berbagai perbaikan pada proses pembelajaran untuk mencapai hasil yang optimal. Perbandingan antar siklus hasil observasi dapat dilihat pada tabel 1 berikut.

Tabel 1. Analisis Hasil Observasi Penerapan Model Auditory Intellectually Repetition Siklus I ,Siklus II dan Siklus III

\begin{tabular}{clllllll}
\hline NO & Langkah -langkah & \multicolumn{2}{c}{ SIKLUS I } & \multicolumn{2}{c}{ SIKLUS II } & \multicolumn{2}{c}{ SIKLUS III } \\
& Guru & Siswa & Guru & Siswa & Guru & Siswa \\
\hline 1 & $\begin{array}{l}\text { Penyampaian materi } \\
\text { (auditory) }\end{array}$ & 77.77 & 65.27 & 88.88 & 81.94 & 94.44 & 94.44 \\
2 & 69.44 & 72.22 & 89.58 & 86.80 & 93.06 & 91.67 \\
$\begin{array}{l}\text { Diskusi kelompok } \\
\text { (intellectually) }\end{array}$ & $\begin{array}{l}\text { Presentasi dan } \\
\text { penyampaian hasil } \\
\text { kelompok (auditory) }\end{array}$ & 74.40 & 69.04 & 83.33 & 83.92 & 91.67 & 89.29 \\
4 & $\begin{array}{l}\text { Pengulangan materi } \\
\text { (repetition) }\end{array}$ & 62.50 & 72.22 & 81.25 & 85.41 & 93.06 & 90.28 \\
\hline Rata -rata & 71.03 & 69.69 & 85.76 & 84.52 & 93.06 & 91.42 \\
\hline
\end{tabular}

Berdasarkan tabel 1 di atas, pembelajaran menggunakan Model Auditory Intellectually Repetition yang dilaksanakan oleh guru dan siswa pada siklus I rata-rata yang diperoleh guru $71,03 \%$ dan rata-rata yang diperoleh siswa $69,69 \%$. Presentase tersebut belum memenuhi indikator penelitian sehingga perlu dilanjutkan ke siklus II. Pembelajaran siklus II dilaksanakan berdasarkan hasil refleksi siklus I dengan harapan adanya peningkatan pada siklus II. Pada siklus II mengalami peningkatan dengan ratarata yang diperoleh guru mencapai $86,76 \%$ dan rata-rata yang diperoleh siswa $84,52 \%$. Hasil penerapan pada guru sudah mencapai indikator kinerja penelitian namun penerapan pada siswa belum mecapai indikator penelitian sehingga perlu adanya refleksi dan dilanjutkan pada siklus III dengan harapan pada siklus III menunjukan hasil yang maksimal. Pada siklus III mengalami peningkatan yang sangat signifikan dimana rata-rata yang diperoleh guru menjadi $93,06 \%$ dan rata-rata yang diperoleh siswa mencapai 91,42\%.

Untuk mengukur hasil belajar siswa, peneliti juga menggunakan data hasil belajar yang menunjukkan adanya peningkatan ketuntasan hasil belajar pada setiap siklusnya. Hasil belajar kognitif yang diukur ialah pada aspek mengingat (C1), memahami (C2), menerapkan (C3), dan menganalisis (C4). Adapun hasil belajar kognitif siswa dapat dilihat pada tabel 2 berikut.

Tabel 2. Analisis Hasil Belajar Peserta Didik Siklus I, Siklus II dan Siklus III

\begin{tabular}{l|l|c|c|c}
\hline No & Siklus & Nilai Rata-Rata & \multicolumn{2}{|c}{ Ketuntasan Siswa } \\
\cline { 3 - 5 } & & & Tuntas (\%) & Tidak Tuntas(\%) \\
\hline 1. & Siklus I & 74.71 & 52.08 & 47.92 \\
2. & Siklus II & 83.69 & 85.42 & 14.58 \\
3. & Siklus III & 90.42 & 95.83 & 4.17 \\
\hline
\end{tabular}

Berdasarkan tabel 2 di atas, hasil belajar siswa pada siklus I nilai rata-rata siswa 74.71 dengan ketuntasan $52.08 \%$. Hasil belajar siswa pada siklus I belum mencapai KKM yang ditentukan yaitu 76 dan belum mencapai indikator ketuntasan yaitu $85 \%$. Hasil belajar siswa pada siklus II terjadi peningkatan yang signifikan dimana nilai rata-rata siswa mencapai 83.69 dengan ketuntasan $85.42 \%$. Hasil belajar siswa pada siklus II sudah mencapai KKM dan sudah mencapai indikator ketuntasan namun 
perlu dilaksanakan siklus III untuk mengetahui hasil belajar yang maksimal. Hasil belajar siswa pada siklus III mendapat nilai rata-rata siswa mencapai 90.42 dengan ketuntasan 95\%. Hasil belajar siswa pada siklus II sudah mencapai KKM dan sudah mencapai indikator ketuntasan sehingga penelitian tentang hasil belajar dapat dihentikan pada siklus III.

Berdasarkan tabel 1 dapat disimpulkan bahwa penerapan model pembelajaran $A I R$ sudah dilaksanakan dengan baik dan sudah mencapai target indikator kinerja penelitian sebesar $85 \%$. Selanjutnya, berdasarkan tabel 2 dapat disimpulkan bahwa hasil belajar PPKn Tema 5 sudah mencapai target indikator kinerja penelitian sebesar $85 \%$ dan meningkat di setiap siklusnya. Hal tersebut sesuai dengan penelitian yang dilakukan oleh Handayani, Suartana, \& Sentosa (2019:09) Berdasarkan hasil penelitian tindakan kelas dan pembahasan dapat disimpulkan implementasi model pembelajaran auditor intellectually repetition (AIR) mampu meningkatkan aktivitas dan hasil belajar siswa hingga mencapai ketuntasan klasikal 100\%. Penelitian lain dilakukan oleh Anwar dan Marudin (2018:39) yang mengatakan bahwa model pembelajaran auditory, intellectualy, repetition (AIR) dapat meningkatkan hasil belajar siswa pada mata pelajaran PKn kelas IV SDN 11 Mataram sub pokok materi pemerintah desa Tahun Pelajaran 2017-2018. Diperkuat oleh penelitian yang dilakukan oleh Syahliani, Jamal, dan An 'nur (2014:213) yang membuktikan bahwa penggunaan model $A I R$ dapat meningkatkan hasil belajar siswa sekolah dasar.

Kendala yang dialami oleh guru pada penelitian ini yaitu: (a) guru belum maksimal dalam memberi stimulus siswa untuk bertanya; (b) guru tidak terlalu mengawasi siswa dalam mengerjakan kuis atau tugas. Solusi yang tepat untuk memperbaiki kendala yang di hadapi oleh guru yaitu: (a) guru memberikan stimulus, memotivasi dan memberikan hadiah kepada siswa yang mampu mengajukan pertanyaan; (b) guru mengawasi siswa dalam mengerjakan kuis dan tidak terpaku pada satu tempat. Sedangkan Kendala yang dialami oleh siswa yaitu: (a) siswa belum berani mengajukan pertanyaan kepada guru; (b) siswa belum mampu berdiskusi dengan baik; (c) siswa kurang percaya diri pada saat presentasi. Solusi yang telah diterapkan guru untuk mengatasi kendala yang di alami oleh siswa yaitu: (a) guru memotivasi dan memberikan hadiah kepada siswa yang mampu mengajukan pertanyaan; (b) guru membimbing diskusi kelompok; (c) guru melakukan bimbingan dan motivasi sehingga siswa percaya diri dalam presentasi

\section{SIMPULAN}

Berdasarkan uraian hasil penelitian dan pembahasan, maka dapat disimpulkan bahwa: (1) penerapan model AIR dengan empat langkah yaitu: (a) penyampian materi (auditory); (b) diskusi kelompok (intellectually); (c) penyampaian hasil diskusi kelompok (auditory); (d) pengulangan materi (repetition) Hasil observasi penerapan model auditory intellectually repretition terhadap guru pada siklus I mencapai persentase $71,03 \%$ dan siswa $69.69 \%$. Pada siklus II hasil observasi terhadap guru yaitu $85,76 \%$ dan siswa 84.52. Selanjutnya pada siklus III hasil observasi terhadap guru yaitu 93,06\% dan siswa 91.42; (2) penerapan model $A I R$ dapat meningkatkan hasil belajar PPKn tema 5 kelas III SD N 5 Panjer tahun 2019/2020, hal ini dapat dibuktikan dari ketuntasan hasil belajar siswa setiap siklus meningkat yaitu pada siklus I 52,08\%, siklus II 85,42\%, dan siklus III mencapai 95,83\%; (3) Kendala yang dialami oleh guru pada penelitian ini yaitu: (a) guru belum maksimal dalam memberi stimulus siswa untuk bertanya; (b) guru tidak terlalu mengawasi siswa dalam mengerjakan kuis atau tugas. Solusi yang tepat untuk memperbaiki kendala yang di hadapi oleh guru yaitu: (a) guru memberikan stimulus, memotivasi dan memberikan hadiah kepada siswa yang mampu mengajukan pertanyaan; (b) guru mengawasi siswa dalam mengerjakan kuis dan tidak terpaku pada satu tempat. Sedangkan Kendala yang dialami oleh siswa yaitu: (a) siswa belum berani mengajukan pertanyaan kepada guru; (b) siswa belum mampu 
berdiskusi dengan baik; (c) siswa kurang percaya diri pada saat presentasi. Solusi yang telah diterapkan guru untuk mengatasi kendala yang di alami oleh siswa yaitu: (a) guru memotivasi dan memberikan hadiah kepada siswa yang mampu mengajukan pertanyaan; (b) guru membimbing diskusi kelompok; (c) guru melakukan bimbingan dan motivasi sehingga siswa percaya diri dalam presentasi.

\section{DAFTAR PUSTAKA}

Agustina, S.,Santoso, E., \&Jatisunda, M. G. (2019). Pengaruh Kecemasan Matematis Terhadap Kemampuan Berpikir Kritis Melalui Model Auditory Intellectually Repetition. Majalengka: Jurnal Seminar Nasional Pendidikan, FKIP UNMA 2019. Diperoleh 20 November 2019 dari file://C:/Users/Asus/Downloads/92-Article\%20Text-188-1-10-20191025.pdf

Anwar, K., \& Marudin (2018). Penerapan Model Pembelajaran Auditory, Intellectualy, Repetition (AIR) untuk Meningkatkan Hasil Belajar Siswa Kelas IV pada Mata Pelajaran PKn di SDN 11 Mataram. El-Midad Jurnal jurusan PGMI. Vol.10 No.1 2018. Diperoleh 03 November 2019 dari https://journal.uinmataram.ac.id/index.php/elmidad/article/view/589

Arikunto, S. (2013). Prosedur Penelitian: Praktik. Jakarta: Rineka Cipta.

Handayani, F., Suartana, P., \& Sentosa, P.P., (2019). Implementasi Model Pembelajaran Auditory Intellectually Repetition Untuk Meningkatkan Aktivitas Dan Hasil Belajar Siswa. Jurnal ilmu pendidikan. Volume 3, Nomor 1, Juni 2019. Diperoleh 03 Desember 2019 dari https://jurnal.undhirabali.ac.id/index.php/jmk/article/view/727

Huda, M. (2014). Model-Model Pengajaran dan Pembelajaran. Yogyakarta: Pustaka Pelajar.

Linuwih, S \& Sukwati, N. O. E., (2014). Efektivitas Model Pembelajaran Auditory Intelektually Repretition (AIR) Terhadap Pemahaman Siswa Pada Konsep Energi Dalam. Semarang : Jurnal Pendidikan Fisika. Diperoleh 06 Desember 2019 dari https://journal.unnes.ac.id/nju/index.php/JPFl/article/view/3451

Manurung, H. S., (2016). Upaya Meningkatkan Kreativitas Dan Hasil Belajar Matematika Siswa Dengan Menggunakan Model Air (Auditory, Intellectually, Repetition) Pada Siswa Kelas VIII MTS Negeri Rantauprapat T.P 2014/2015. Medan :Jurnal EduTech Vol. 2 No. 1. Diperoleh 29 November 2019 dari http://jurnal.umsu.ac.id/index.php/edutech/article/view/580

Departemen Pendidikan Nasional, Peraturan Pemerintah Republik Indonesia Nomor 32 Tahun 20013 tentang Perubahan atas Peraturan Pemerintah No 19 Tahun 2005 Tentang Standar Nasional Pendidikan, Jakarta: Departemen Pendidikan Nasional. Di unduh dari http://pelayanan.jakarta.go.id/download/regulasi/peraturan-pemerintahnomor-19-tahun-2005-tentang-standar-pendidikan-nasional.pdf

Shoimin, A., 2014. 68 Model Pembelajaran Inovatif dalam Kurikulum 2013. Yogyakarta: Ar-Ruzz Media.

Sugiyono, (2016). Metode Penelitian Pendidikan (Pendekatan Kuantitatif, Kualitatif, dan R\&D). Bandung: Alfabeta.

Syahliani, M. Jamal, M. A., \& An'nur, S. (2014). Penerapan Model Pembelajaran Auditory Intellectually Repetition (AIR) Untuk Meningkatkan Hasil Belajar Siswa. Berkala IImiah Pendidikan Fisika, 2(3), 213-221. 